\title{
Transformasi Teks Sejarah Pertempuran Kotabaru ke dalam Teks Beksan Bedhaya Ngadilaga Kotabaru
}

\author{
Oleh: \\ SUSI SETYANINGSIH \\ NIM. 1211419011
}

Jurusan Tari, Fakultas Seni Pertunjukan, Institut Seni Indonesia Yogyakarta

\begin{abstract}
RINGKASAN
Beksan Bedhaya Ngadilaga Kotabaru merupakan karya tari yang menggunakan sumber materi dramatik fakta sejarah pertempuran 7 Oktober 1945 di Kotabaru, Yogyakarta. Dilihat dari motif geraknya tarian ini menggunakan pola-pola gerak dalam tari putri gaya Yogyakarta. Permasalahan yang ingin dikaji dalam penelitian ini adalah bagaimana fakta sejarah pertempuran Kotabaru ditransformasikan ke dalam sebuah karya tari, yaitu Beksan Bedhaya Ngadilaga Kotabaru.

Identifikasi teks sejarah pertempuran Kotabaru dan teks Beksan Bedhaya Ngadilaga Kotabaru akan disandingkan dan dikaji untuk diketahui aspek apa saja yang bertransformasi. Dengan menggunakan teori interteks peneliti akan mengungkap permasalahan dan memberikan penjelasan tentang unsur-unsur intrinsik yang meliputi masalah pokok dan tema, setting/latar, alur, penokohan, dan nilai-nilai untuk melihat proses transformasinya. Unsur-unsur intrinsik pada teks bedhaya di Keraton Yogyakarta, teks sejarah pertempuran Kotabaru, serta teks Beksan Bedhaya Ngadilaga Kotabaru dianalisis untuk diketahui model-model transformasinya.

Hasil analisis kedua teks yang disandingkan membuktikan adanya unsur-unsur yang sama dan ditafsir sebagai unsur-unsur yang bertransformasi dari teks sejarah pertempuran Kotabaru ke dalam teks Beksan Bedhaya Ngadilaga Kotabaru. Kelima unsur yang bertransformasi dari teks sejarah pertempuran Kotabaru ke dalam teks Beksan Bedhaya Ngadilaga Kotabaru merupakan bukti adanya resepsi yang baik oleh penata tari dalam menyusun Beksan Bedhaya Ngadilaga Kotabaru. Transformasi yang ditemukan dalam penelitian ini yakni transformasi yang bersifat meneruskan/melanjutkan hipogramnya dan transformasi yang bersifat mematahkan hipogramnya.
\end{abstract}

Kata kunci: patriotisme, transformasi, bedhaya.

\section{ABSTRACT}

Beksan Bedhaya Ngadilaga Kotabaru is a dance piece that uses a material source of dramatic historical facts October 7, 1945 battle in Kotabaru, Yogyakarta. Viewed from this dance motif motion patterns of movement in dance style princess Yogyakarta. The problems to be examined in this study is how the battle Kotabaru historical fact transformed into a dance work, namely Beksan Bedhaya Ngadilaga Kotabaru .

Identification of historical text battle on Kotabaru and Beksan Bedhaya Ngadilaga Kotabaru text will paired and will studied to know what aspects are transformed. By using the theory of intertextual researchers will unravel the problems and provide an explanation of the intrinsic elements covering subject matter and themes, setting/background, plot, characterization, and values to see its transformation process. The intrinsic elements become a one which analogized 
and become the study material so produce a answer of the research, that are main transformation problem and theme, setting, plot, characteritation, and the value in Beksan Bedhaya Ngadilaga Kotabaru. The intrinsic elements of the text bedhaya at Keraton Yogyakarta, Kotabaru battle history text, and text Beksan Bedhaya Ngadilaga Kotabaru analyzed for known models of transformation.

The result of analysis of both of texts which paired prove there're same elements and interpreted as elements which do transformation from historical text battle Kotabaru in to Beksan Bedhaya Ngadilaga Kotabaru text. The five elements which do transformation from historical text battle Kotabaru in to Beksan Bedhaya Ngadilaga Kotabaru text is a proof of good reception by choreographer in compose Beksan Bedhaya Ngadilaga Kotabaru. The transformation that was found in this research that are transformation forward/continue the hipogram and transformation that are break the hipogram.

Key words: patriotism, transformation, bedhaya.

\section{PENDAHULUAN}

\section{A. Permasalahan Transformasi dalam Beksan Bedhaya Ngadilaga Kotabaru}

Bedhaya Ngadilaga Kotabaru merupakan karya tari yang disusun oleh W. Ragamulya, seorang penata tari sekaligus penata iringan yang berdomisili di Kota Yogyakarta. Karya tari yang diberi nama Beksan Bedhaya Ngadilaga Kotabaru ini berdurasi kurang lebih satu jam yang dipentaskan pertama kalinya di Bangsal Sri Manganti, Keraton Yogyakarta pada Minggu, 15 Juni 2014 dilakukan untuk keperluan pariwisata di Bangsal Sri Manganti, Keraton Yogyakarta yang biasa rutin diselenggarakan setiap hari Minggu. (Wawancara dengan W. Ragamulya pada hari Kamis, 26 November 2015. Pukul 14: 35 WIB. Diizinkan untuk dikutip.)

Sama halnya dengan jumlah penari bedhaya pada umumnya, Beksan Bedhaya Ngadilaga Kotabaru ditarikan oleh 9 penari putri. Kesembilan penari masing-masing memiliki peran sebagai Endhel Pajeg (1), Batak (2), Jangga (3), Dhadha (4), Bunthil (5), Apit Ngajeng (6), Apit Wingking (7), Endhel Wedalan Ngajeng (8), dan Endhel Wedalan Wingking (9). (Y. Sumandiyo Hadi. 2012. Koreografi Bentuk-Teknik-Isi. Yogyakarta :
Cipta Media. P. 67. ) Penomoran tersebut yang biasa digunakan untuk memudahkan penyebutan peran dari masing-masing penari yang berbeda peran antara penari satu dengan yang lainnya.

Hal yang hampir ada pada setiap bedhaya, khususnya yang ada di Yogyakarta pada umumnya memiliki sumber cerita yang dijadikan sebagai sumber materi dramatik penyusunan beksan bedhaya tersebut oleh koreografernya. Sumber materi dramatik biasanya menjadi inspirasi koreografer dalam menyusun bedhaya agar pesan yang ingin disampaikan melalui bedhaya bisa diketahui oleh orang lain yang menyaksikan bedhaya tersebut saat dipentaskan. Pada bagian tertentu dalam pertunjukan bedhaya akan ada penekanan maksud/pesan dari koreografernya melalui pola lantai dan pola gerak yang dilakukan penari bedhaya.

Beksan Bedhaya Ngadilaga Kotabaru yang belum lama tersusun ini juga tidak berdeda jauh dengan bedhaya-bedhaya yang sudah ada sebelumnya. Beksan Bedhaya Ngadilaga Kotabaru ini mempunyai sumber materi dramatik dari sebuah peristiwa nyata yakni teks sejarah. Sejarah yang dimaksud adalah sejarah pertempuran yang merupakan bagian dari salah satu sejarah Bangsa Indonesia yang terjadi di wilayah Kotabaru, Yogyakarta. Peristiwa bersejarah ini dijadikan 
sebagai sumber materi dramatik dalam Beksan Bedhaya Ngadilaga Kotabaru oleh W. Ragamulya yang pada inti dari cerita sejarah tersebut adalah pertempuran bangsa Indonesia melawan pemerintah Jepang di Kotabaru, Yogyakarta.

Dalam peristiwa pertempuran di Kotabaru tersebut akhirnya para pejuang Indonesia berhasil merebut markas Jepang dan melucuti senjata para tentara Jepang yang kalah dalam pertempuran. Peristiwa pertempuran di Kotabaru mengakibatkan gugurnya banyak pejuang bangsa. Kala itu sebanyak 21 pejuang Yogyakarta wafat. ( Wawancara dengan Bagus S. pada Selasa, 8 Maret 2016 pukul 09.46 WIB. Diizinkan untuk dikutip.) Sebagai penghormatan maka dibangun sebuah monumen di Kotabaru dengan mencantumkan nama para pejuang yang telah gugur tersebut.

Peneliti tertarik dengan teks sejarah pertempuran Kotabaru dan menjadikannya sebagai bahan kajian ketika teks tersebut menjadi inspirasi koreografer sehingga dapat diwujudkan dalam bentuk lain yakni ke dalam seni pertunjukan. Berangkat dari teks sejarah tersebut kemudian oleh koreografer (W. Ragamulya) diinterpretasikan dan dituangkan ke dalam Beksan Bedhaya Ngadilaga Kotabaru. Serangkaian dari peristiwa menjelang dan pada saat terjadinya pertempuran di Kotabaru yang begitu panjang ini tidak semuanya digambarkan dalam Beksan Bedhaya Ngadilaga Kotabaru, tetapi hanya ada beberapa aspek dari peristiwa pertempuran di Kotabaru yang disajikan dalam Beksan Bedhaya Ngadilaga Kotabaru.

Hal lain yang menjadi alasan mengapa tidak semua rangkaian peristiwa dari teks sejarah pertempuran Kotabaru dituangkan dalam Beksan Bedhaya Ngadilaga Kotabaru, yang pertama karena koreografer mengambil beberapa unsur dramatik dari serangkaian peristiwa sejarah pertempuran Kotabaru yang dianggap penting dan akan ditonjolkan dalam Beksan Bedhaya Ngadilaga Kotabaru. Kedua, karena aspek waktu; waktu yang lama dari keseluruhan rangkaian peristiwa sejarah pertempuran Kotabaru tersebut tidak memungkinkan bisa tertuang dalam bentuk Beksan Bedhaya Ngadilaga Kotabaru yang hanya berdurasi kurang lebih satu jam sehigga itu menjadi pertimbangan koreografer dalam mneyusun bedhaya tersebut. Ketiga, karena aspek koreografi yang dilihat dari sudut pandang koreografer yang memperhitungkan nilai estetis koreografi dalam bentuk penyajian Beksan Bedhaya Ngadilaga Kotabaru.

Beksan Bedhaya Ngadilaga Kotabaru ini merupakan hasil kreatifitas seni si penata tari dalam mengembangkan sumber materi dramatik yang menginspirasinya. Koreografer mengemasnya dalam bentuk tari bedhaya yang mengenakan tata rias dan busana yang sama pada kesembilan penarinya. Penggunaan pistol mainan sebagai properti tari dipilih oleh penata tari untuk memperkuat sumber materi dramatik tentang teks sejarah pertempuran dalam Bedhaya Ngadilaga Kotabaru. Tembakan yang dihasilkan dari pistol mainan dimaksudkan agar ide cerita dalam bedhaya tersebut dapat dipahami oleh orang lain yang menyaksikannya. Properti akan digunakan oleh kesembilan penari sebagai klimaks tarian pada bagian perangan. Hal inilah yang menjadi alasan penggunaan properti pistol dalam Beksan Bedhaya Ngadilaga Kotabaru ini.

Berangkat dari sumber cerita sejarah pertempuran Kotabaru yang dijadikan sebagai sumber materi dramatik, judul, dan strukstur tarinya maka bisa dianalisis adanya sebuah transformasi dari teks sejarah pertempuran Kotabaru ke dalam teks seni pertunjukan yakni Beksan Bedhaya Ngadilaga Kotabaru. Dikatakan bahwa teks sejarah tersebut telah beralih rupa atau bentuk, yakni bentuk teks menjadi bentuk seni pertunjukan Beksan Bedhaya Ngadilaga Kotabaru.

Kata transformasi diterjemahkan sebagai alih-rupa atau malih dalam bahasa Jawa Ngoko. Artinya, dalam suatu transformasi yang berlangsung adalah sebuah perubahan pada tataran permukaan, sedang pada tataran yang lebih dalam lagi perubahan tersebut tidak terjadi.( Heddy Shri Ahimsa- 
Putra. 2001. "Strukturalisme Levi-Strauss Mitos Dan Karya Satra". Yogyakarta : Galang Press. P. 62.) Dalam Kamus Besar Bahasa Indonesia mengartikan transformasi sebagai perubahan rupa (bentuk, sifat). ( Tim penyusun kamus Pusat Pembinaan dan Pengembangan Bahasa. 1995. "Kamus Besar Bahasa Indonesia". Jakarta : Perum Balai Pustaka. P. 1.070.) Hal tersebut hampir serupa dengan arti kata transformasi menurut John Echlos dan Hasan Shadily dalam buku yang ditulis oleh Sumaryono bahwa transformasi diartikan sebagai perubahan bentuk, menjadi. ( Sumaryono. 2003. "Restorasi Seni Tari dan Transformasi Budaya". Yogyakarta : Elkaphi (Lembaga Kajian Pendidikan dan Humaniora Indonesia). P. 96.) Makna kunci untuk istilah transformasi adalah perubahan, yaitu perubahan terhadap suatu hal atau keadaan. (Burhan Nurgiyantoro. 1998."Transformasi Unsur Pewayangan dalam Fiksi Indonesia". Yogyakarta: Gadjah Mada University Press. P. 18.) Jadi arti kata transformasi pada intinya adalah suatu perubahan bentuk atau alih rupa dari suatu aspek menjadi hal baru yang tidak sepenuhnya meninggalkan esensi dasar dari aspek yang ditransformasikan serta dapat dilihat hasilnya. Dalam hal ini adalah teks sejarah pertempuran di Kotabaru menjadi sebuah tarian, Beksan Bedhaya Ngadilaga Kotabaru.

Sejarah pertempuran Kotabaru dan Bedhaya Ngadilaga Kotabaru adalah dua hal yang sama-sama merupakan sebuah teks. Dalam dunia sastra, teori interteks memandang bahwa sebuah teks yang ditulis lebih kemudian mendasarkan diri pada teks-teks lain yang telah ditulis orang sebelumnya. Teeuw menyatakan bahwa tidak ada sebuah teks pun yang sungguh-sungguh mandiri, dalam arti penciptaannya dengan konsekuensi pembacaannya juga, dilakukan tanpa sama sekali berhubungan dengan teks lain yang dijadikan semacam contoh, teladan, kerangka, atau acuan. (Burhan Nurgiyantoro. 1998. "Transformasi Unsur Pewayangan dalam Fiksi Indonesia".Yogyakarta: Gadjah Mada University Press. P. 15.) Pemahaman teori ini bisa juga dianalogikan dalam dunia seni pertunjukan khususnya tari. Dalam hal ini mempertegas bahwa teks sejarah pertempuran dan teks Beksan Bedhaya Ngadilaga Kotabaru adalah dua buah teks yang saling berelasi satu sama lain. Selain dua teks yang menjadi fokus penelitian ini, masih ada teks-teks lainnya yang juga berperan penting karena saling terkait satu dengan yang lainnya. Salah satu contohnya yakni teks bedhaya keraton yang juga menjadi hipogram. Masing-masing teks tersebut akan diidentifikasi sehingga peneliti akan mampu mengkaji interteks yang ada di dalamnya.

Transformasi teks sejarah dalam wujud seni pertunjukan mengalami perbedaan wujud dari kejadian yang sebenarnya terjadi pada saat pertempuran. Meskipun demikian aspek-aspek yang ada dalam Beksan Bedhaya Ngadilaga Kotabaru tidak meninggalkan aspek-aspek yang terdapat dalam teks sejarah pertempuran Kotabaru. Melalui karya tari itu diharapkan dapat dipahami gambaran pertempuran yang terjadi pada tanggal 7 Oktober 1945 di Kotabaru. Pada akhirnya peneliti menghadirkan dua bentuk teks yang dijadikan kajian penelitian. Kedua teks tersebut yakni sejarah pertempuran Kotabaru dan Beksan Bedhaya Ngadilaga Kotabaru. Kedua teks akan disandingkan untuk dianalisis secara lebih dalam yang kemudian akan diketahui hal-hal apa saja yang ditransformasikan dari sejarah ke dalam bentuk tarian. Dalam hal ini peneliti hendak membahas lebih lanjut mengenai aspek apa saja yang menjadi hasil dari proses transformasi teks sejarah ke dalam teks seni pertunjukan yakni Beksan Bedhaya Ngadilaga Kotabaru.

\section{B. Pendekatan yang digunakan oleh peneliti}

Untuk menjawab permasalahan penelitian di atas maka peneliti berupaya dengan cara mempergunakan teori yang dimiliki oleh peneliti lain yang sudah pernah melakukan penelitian yang hampir serupa dengan penelitian ini. Teori yang 
dipergunakan adalah teori interteks yang diterapkan Burhan dalam kajiannya yakni mengulas tentang Transformasi Unsur Pewayangan dalam Fiksi Indonesia. Selain teori interteks, Burhan juga menggunakan konstruk teoretis yang sengaja disusun untuk mendekati permasalahan yang diteliti. Teori dan konstruk teoretis yang diterapkan Burhan dalam kajiannya sangat membantu peneliti dalam mengkaji transformasi teks sejarah ke dalam teks seni pertunjukan meskipun dalam kajian yang dilakukan oleh Burhan adalah di dunia sastra. Dalam penelitiannya, Burhan menerapkan teori interteks yang akan dianalogikan dalam permasalahan teks seni pertunjukan.

Teori interteks akan dipahami dan diterapkan dalam mengkaji teks sejarah pertempuran dan teks seni pertunjukan Beksan Bedhaya Ngadilaga Kotabaru. Dalam analisisnya maka konstruk teoretis yang sengaja dibuat oleh peneliti untuk mendekati permasalahan penelitian ini yakni mempertegas (1). Teks Sejarah Pertempuran Kotabaru, dan (2). Teks Seni Pertunjukan Beksan Bedhaya Ngadilaga Kotabaru. kedua konstruk inilah yang nantinya akan membantu peneliti dalam mengetahui unsur-unsur apa saja yang bertransformasi.

Hal lain yang dipergunakan oleh peneliti untuk mendukung teori interteks tersebut yakni menggunakan pula suatu pendekatan koreografi. Pendekatan koreografi digunakan untuk mendukung kajian penelitian ini karena bagaimana pun Beksan Bedhaya Ngadilaga Kotabaru merupakan sebuah koreografi, lain halnya dengan teks sejarah yang merupakan peristiwa nyata di masa lampau. Meskipun demikian, kedua hal tersebut pada dasarnya memiliki interelasi teks yang saling terkait. Keterkaitan tersebut diantaranya yakni tekssejarah yang dijadikan inspirasi dramatiknya dan akan tetap melibatkan teks lain yang sebelumnya ada sebagai hipogramnya juga sehingga pada tahap analisis nanti peneliti bisa mengelaborasikan teori interteks karya sastra dalam karya tari dengan didukung pendekatan koreografi.
Pendekatan koreografi dalam penelitian ini menggunakan konsep-konsep koreografi oleh Y. Sumandiyo Hadi. Aspek-aspek koreografi oleh Y. Sumandiyo Hadi bisa diterapkan dalam pembahasan permasalahan penelitian yang dipandang sebagai teks, Beksan Bedhaya Ngadilaga Kotabaru.

Pustaka untuk membantu dalam penerapan pendekatan tersebut yakni buku yang berjudul Transformasi Unsur Pewayangan dalam Fiksi Indonesia oleh Burhan Nurgiyantoro tahun 1998 dan buku yang ditulis oleh Y. Sumandiyo Hadi yang berjudul Kajian Tari Teks dan Konteks pada Cetakan I tahun 2007. Kedua buku ini yang dijadikan panduan dalam menganalisis data-data dalam penelitian sehingga data-data yang diperoleh dapat diolah, ditelaah, dan dikaji menjadi sebuah hasil penelitian yang mampu menjawab permasalah penelitian.

\section{Metode penelitian yang diterapkan oleh peneliti}

Masalah penelitian tentang teks sejarah pertempuran Kotabaru yang ditransformasikan dalam teks Beksan Bedhaya Ngadilaga Kotabaru tidak mudah untuk dijawab apabila tidak menggunakan suatu metode penelitian yang secara tepat dan benar. Dalam hal ini peneliti memilih metode penelitian ini dengan metode Deskriptif Analisis. Deskriptif Analisis merupakan metode yang sering digunakan dalam penelitian di bidang seni yang menekankan pada usaha peneliti untuk mendeskripsikan suatu objek penelitian secara baik yang bersumber dari data-data yang diperoleh kemudian mencoba menganalis atau menelaahnya untuk menjawab permasalahan penelitian. Melalui metode ini pula peneliti mempunyai tugas untuk mengungkap permasalahan yang timbul pada objek penelitian dengan cara pengumpulan data-data yang valid kemudian menganalis dan mempertanggungjawabkannya dalam sebuah paparan secara tertulis, dalam hal ini mengenai proses transformasi teks sejarah ke dalam teks seni pertunjukan tari yakni Beksan Bedhaya 
Ngadilaga Kotabaru. Dalam hal ini objek material penelitian adalah tari yang bernama Beksan Bedhaya Ngadilaga Kotabaru karya W. Ragamulya, sedangkan objek formalnya yakni penerapan teori interteks pada konsep tranformasi dalam karya sastra yang kemudian dianalogikan dan diterapkan dalam karya tari yang didukung sebuah pendekatan koreografi untuk menjawab masalah penelitian.

\section{PEMBAHASAN}

\section{A. Pengertian Transformasi}

Transformasi merupakan salah satu cara yang bisa dipergunakan oleh seseorang dalam upayanya membuat suatu hasil karya dari inspirasi, ide, atau sumber materi yang menjadi referensinya. Hal ini menjadi bukti bahwa transformasi sudah bisa dijadikan sebagai suatu sarana media ungkap seseorang dalam berkarya sesuai dengan bidang yang digelutinya. Transformasi suatu hal ke hal lain telah banyak contohnya, terlebih sudah banyak peneliti yang menganalisis suatu objek dengan permasalahan transformasi menjadi sebuah bahan kajiannya.

Transformasi bisa dipahami dalam beberapa pengertian, yakni transformasi yang diterjemahkan sebagai alih-rupa atau malih dalam bahasa Jawa Ngoko. Artinya, dalam suatu transformasi yang berlangsung adalah sebuah perubahan pada tataran permukaan, sedang pada tataran yang lebih dalam lagi perubahan tersebut tidak terjadi.( Heddy Shri Ahimsa-Putra. 2001. "Strukturalisme LeviStrauss Mitos Dan Karya Satra". Yogyakarta : Galang Press. P. 62.) Dalam Kamus Besar Bahasa Indonesia mengartikan transformasi sebagai perubahan rupa (bentuk, sifat). (Tim penyusun kamus Pusat Pembinaan dan Pengembangan Bahasa. 1995. "Kamus Besar Bahasa Indonesia". Jakarta : Perum Balai Pustaka. P. 1.070.) Hal tersebut hampir serupa dengan arti kata transformasi menurut John Echlos dan Hasan Shadily dalam buku yang ditulis oleh Sumaryono bahwa transformasi diartikan sebagai perubahan bentuk, menjadi.
(Sumaryono. 2003. "Restorasi Seni Tari dan Transformasi Budaya". Yogyakarta : Elkaphi (Lembaga Kajian Pendidikan dan Humaniora Indonesia). P. 96.) Makna kunci untuk istilah transformasi adalah perubahan, yaitu perubahan terhadap suatu hal atau keadaan. (Burhan Nurgiyantoro. 1998."Transformasi Unsur Pewayangan dalam Fiksi Indonesia". Yogyakarta: Gadjah Mada University Press. P. 18.) Jadi arti kata transformasi pada intinya adalah suatu perubahan bentuk atau alih rupa dari suatu aspek menjadi hal baru yang tidak sepenuhnya meninggalkan esensi dasar dari aspek yang ditransformasikan serta dapat dilihat hasilnya.

Pada intinya transformasi merupakan sebuah proses sebagai upaya seseorang dalam menuangkan sebuah ide ke dalam hal baru yang dipengaruhi oleh suatu hal sebagai sumber inspirasinya. Dalam hal ini ditegaskan dengan argumen Tony Rudyansjah bahwa:

Manusia harus berpikir dalam satu kerangka kebudayaan tertentu: yang bisa dilakukannya adalah menyesuaikan, memodifikasi, dan paling jauh mentransformasi apa-apa yang sudah tersedia di dalam jagad raya kebudayaannya agar sesuai dengan aspirasi dan kepentingan yang dihadapinya saat itu. (Tony Rudyansjah. 2009. "Kekuasaan, Sejarah, \& Tindakan: Sebuah kajian tentang lanskap budaya." Jakarta: Rajawali Pers. P. 236.)

Transformasi tidak akan meninggalkan apa yang menjadi hipogramnya. Istilah hipogram sering digunakan dalam teori interteks karya sastra dalam proses transformasi. Hipogram merupakan karya, tradisi, dan konvensi sebelumnya yang dipandang sebagai suatu tantangan yang perlu disikapi, yang dijadikan dasar bagi penulisan karya lain sesudahnya.(Burhan Nurgiyantoro. 1998."Transformasi Unsur Pewayangan dalam Fiksi Indonesia". Yogyakarta: Gadjah Mada University Press. P.15.) Pemahaman tentang hipogram tersebut digunakan oleh peneliti dalam analisis penelitian terkait permasalahan transformasi. 
Pemahaman dalam teori interteks karya sastra menekankan bahwa suatu teks tidak dapat berdiri sendiri. A. Teeuw menegaskan bahwa: tidak ada sebuah teks pun yang sungguhsungguh mandiri, dalam arti penciptaannya dengan konsekuensi pembacaannya juga, dilakukan tanpa sama sekali berhubungan dengan teks lain yang dijadikan semacam contoh, teladan, kerangka, atau acuan. ( Burhan Nurgiyantoro. 1998.'Transformasi Unsur Pewayangan dalam Fiksi Indonesia". Yogyakarta: Gadjah Mada University Press. P. 15.)

Teks-teks yang berkaitan dengan proses transformasi akan dianalisis dan ditafsir sebagai hasil dari proses transformasi tanpa mengabaikan suatu teks yang berada di dalamnya. Teks tersebut menjadi acuan dari teks-teks yang bertransformasi ke dalam teks lain yang menjadi hasil dari proses transformasi. Kinerja tersebut bisa terwujud melalui berbagai cara dalam membaca teks dengan disiplin ilmu yang dianggap cocok untuk digunakan.

Teori interteks yang ada dalam dunia sastra dan biasa digunakan dalam analisis teks karya sastra kini oleh peneliti digunakan dalam analisis teks dalam seni pertunjukan. Penggunaan teori interteks dipandang mampu untuk membantu peneliti dalam mengidentifikasi teks-teks sebagai sumber data dalam proses transformasi. Hal ini merupakan langkah kerja Burhan Nurgiantoro yang menggunakan teori interteks dalam dunia sastra yang salah satunya dipelopori oleh A. Teeuw (tokoh sastra) yakni yang tertuang dalam buku karya Burhan yang berjudul "Transformasi Unsur Pewayangan dalam Fiksi Indonesia". Burhan Nurgiyantoro adalah satu dari sekian banyak peneliti yang membahas tentang transformasi dalam kajiannya.

Teori interteks memandang bahwa sebuah teks yang ditulis lebih kemudian mendasarkan diri pada teks-teks lain yang telah ditulis orang sebelumnya.(Burhan Nurgiyantoro. 1998."Transformasi Unsur Pewayangan dalam Fiksi Indonesia".
Yogyakarta: Gadjah Mada University Press. P. 15.) Teks tidak dapat berdiri sendiri tanpa adanya hubungan dengan teks lain yang mendukungnya. Teks-teks yang dibaca oleh peneliti merupakan langkah awal dalam mengkaji sebuah transformasi. Hal demikian sebagai cara untuk menjawab permasalahan yang dimunculkan dalam penelitian ini.

Teori interteks dalam karya sastra mengenal adanya unsur-unsur intrinsik yang bisa dijadikan sebagai acuan dalam mengidentifikasi aspek-aspek yang bertransformasi pada teks yang dikaji. Sama halnya yang dilakukan Burhan dalam penelitiannya yakni dengan melibatkan unsurunsur intrinsik sebagai hasil dari proses transformasi unsur pewayangan. Dengan mengacu pada langkah kerja Burhan maka peneliti juga menggunakan istilah unsur instrinsik karya sastra dalam menganalisis teks yang telah diperoleh. Unsur-unsur intrinsik yang digunakan diantaranya yakni unsur masalah pokok dan tema, setting/latar, alur, penokohan, dan nilai-nilai.

Unsur-unsur instrinsik yang dilibatkan dalam penelitian tentang transformasi akan bekerja maksimal apabila peneliti bisa teliti dan tepat dalam menelaah data dari teks satu ke dalam teks yang lainnya. Sesuai dengan langkah kerja Burhan bahwa kelima unsur intrinsik yang disebutkan tadi merupakan langkah awal dalam penemuan hasil transformasi. Langkah kerja yang pertama yakni dengan cara membandingkannya antara teks satu dengan teks lain. (Burhan Nurgiyantoro. 1998."Transformasi Unsur Pewayangan dalam Fiksi Indonesia". Yogyakarta: Gadjah Mada University Press. P. 20.) Selanjutnya, peneliti akan melakukan langkah kerja yang hampir serupa dengan apa yang telah dilakukan Burhan dalam kajian transformasi teks seni pertunjukan yakni bedhaya. Transformasi yang ada dalam teks ini akan ditemukan dengan penggunaan teori interteks dan hal-hal yang telah dibicarakan sebelumnya tentang pemahaman hipogram, unsur-unsur intrinsik dalam sastra, dan pemahaman teori interteks yang 
dianalogikan oleh peneliti ke dalam kajian transformasi teks non karya sastra, yakni teks sejarah dan teks seni pertunjukan.

Transformasi teks sejarah pertempuran Kotabaru ke dalam teks seni pertunjukan, Beksan Bedhaya Ngadilaga Kotabaru pada hakikatnya merupakan sebuah resepsi aktif penata tari terhadap teks sejarah pertempuran Kotabaru itu. Resepsi estetik (esthetics of reception) dapat dideskripsikan sebagai kerja yang mengumpulkan teks kesastraan berdasarkan kemungkinan tanggapan pembaca.(Burhan Nurgiyantoro. 1998 ."Transformasi Unsur Pewayangan dalam Fiksi Indonesia". Yogyakarta: Gadjah Mada University Press. P. 10.) Meskipun teori resepsi lazim digunakan dalam dunia sastra, kali ini teori resepsi bisa digunakan dalam dunia seni pertunjukan dimana seorang penata tari juga bisa melakukan sebuah resepsi atas apa yang telah diketahui, dibaca, dan diresapinya dari sebuah tulisan atau fenomenafenomena kehidupan yang dapat dijadikan sebagai bahan perenungan guna dijadikannya sebagai inspirasi dalam berkarya.

Transformasi pada teks sejarah ke dalam teks seni pertunjukan ini menunjukkan adanya penerimaan penata tari terhadap teks sejarah pertempuran Kotabaru sebagai sumber inspirasinya yang kemudian dituangkan dalam karyanya. Penerimaan itu akan dipengaruhi oleh jati dirinya, misalnya yang berupa sikap, persepsi, pandangan hidup, rasa memiliki, lingkungan hidup, pendidikan, dan lain-lain yang menyebabkan penerimaan seorang pengarang menjadi berbeda dengan pengarang yang lain. (Burhan Nurgiyantoro. 1998. "Transformasi Unsur Pewayangan dalam Fiksi Indonesia". Yogyakarta: Gadjah Mada University Press. P. 177.) Penata tari yakni W. Ragamulya menginterpretasikan teks sejarah pertempuran Kotabaru itu ke dalam Beksan Bedhaya Ngadilaga Kotabaru dengan tidak meninggalkan kaidah-kaidah yang ada pada bedhaya yang sudah ada sebelumnya.

\section{B. Model Transformasi}

Model transformasi yang ditemukan dalam penelitian yang dilakukan Burhan, yang diacu oleh peneliti dalam analisis ini yakni model transformasi dengan pemunculan, pengambilan, atau pemindahan unsur-unsur dengan perubahan. Unsur-unsur tersebut yakni unsur-unsur dalam teks sejarah pertempuran Kotabaru yang dimunculkan dalam teks Beksan Bedhaya Ngadilaga. Dengan demikian, unsur-unsur yang bertransformasi akan muncul atau nampak berbeda dengan unsur-unsur aslinya, yakni peristiwa sejarah pertempuran Kotabaru ke dalam Beksan Bedhaya Ngadilaga Kotabaru.

Dalam fenomena yang ditemukan dalam teks Beksan Bedhaya Ngadilaga Kotabaru akan berbeda dengan model transformasi yang telah dijelaskan di atas. Pada bagian ragam gerak yang ditafsir dengan unsur-unsur intrinsik akan ditemukan adanya model transformasi yang sifatnya tidak meneruskan dari teks yang menjadi hipogramnya melainkan transformasi yang sifatnya bertentangan dengan hipogramnya. Hasil ini akan lebih diperjelas pada bagian analisis unsur-unsur yang bertransformasi ke dalam teks Beksan Bedhaya Ngadilaga Kotabaru.

Untuk mendapatkan hasil yang berupa deskripsi transformasi dari teks sejarah pertempuran Kotabaru ke dalam teks Beksan Bedhaya Ngadilaga Kotabaru, maka dilakukan kegiatan analisis terhadap teks yang ditransformasikan dan teks yang menjadi hasil dari proses transformasi, yakni (1) Teks Sejarah Pertempuran Kotabaru dan (2) Teks Beksan Bedhaya Ngadilaga Kotabaru. Kedua teks tersebut diidentifikasi kemudian dikaji dalam proses penelitian sehingga dari kedua teks yang disandingkan tersebut mampu dideskripsikan dengan jelas.

Unsur-unsur yang sama, yang terdapat dalam kedua teks yakni teks sejarah pertempuran Kotabaru dan teks Beksan Bedhaya Ngadilaga Kotabaru akan menjadi bahan yang dianalisis oleh peneliti sebagai 
unsur yang bertransformasi dari teks sejarah pertempuran Kotabaru ke dalam teks seni pertunjukan, Beksan Bedhaya Ngadilaga Kotabaru. Unsur-unsur intrinsik karya sastra yang ditemukan dalam teks sejarah Kotabaru akan disandingkan dengan data-data yang ada dalam teks Beksan Bedhaya Ngadilaga Kotabaru. Dari hasil pembandingan itulah kemudian akan dapat ditentukan unsur-unsur apa saja yang ditransformasikan dari teks sejarah pertempuran Kotabaru pada teks Beksan Bedhaya Ngadilaga Kotabaru.

Dengan adanya dua hipogram yakni teks sejarah pertempuran Kotabaru dan juga pembahasan tentang teks bedhaya keraton, maka akan diketahui tentang proses dan hasil dari resepsi penata tari terkait hadirnya Beksan Bedhaya Ngadilaga Kotabaru.
Meskipun inspirasi dramatik yang utama adalah teks sejarah, namun peran bedhaya keraton yang sudah ada sebelumnya adalah sama pentingnya sebagai referensi dalam penyusunan Beksan Bedhaya Ngadilaga Kotabaru. Usaha pemunculan, pengambilan, dan pemindahan unsur dalam teks sejarah pertempuran Kotabaru oleh penata tari akan nampak ketika kedua teks sama-sama berhasil diidentifikasi secara saksama oleh peneliti. Di sinilah peran peneliti sebagai pembaca dari teks-teks yang saling terkait yang akhirnya menghasilkan sebuah teks baru yakni teks Beksan Bedhaya Ngadilaga Kotabaru. Model transformasi inilah yang akan menjawab permasalahan penelitian.

Dengan demikian, rancangan langkah kerja yang dilakukan peneliti dapat dirinci ke dalam sebuah rancangan penelitian yang lebih konkret dalam bentuk diagram sebagai berikut.

\section{DIAGRAM RANCANGAN PENELITIAN:}

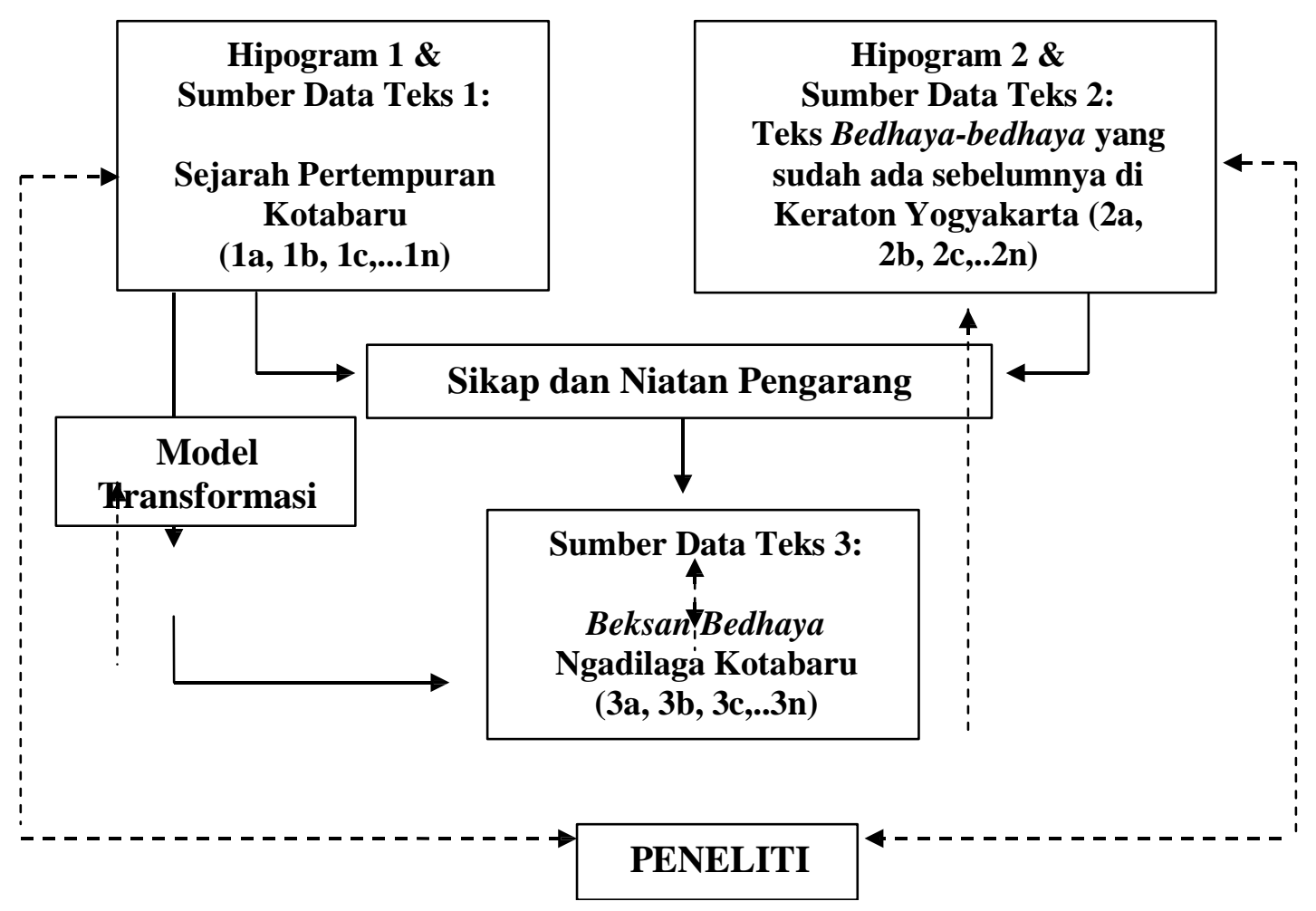




\section{KESIMPULAN}

Berdasarkan hasil pembahasan terkait dengan transformasi teks sejarah pertempuran Kotabaru ke dalam teks Beksan Bedhaya Ngadilaga Kotabaru, maka analisis ini akan disimpulkan dengan mengacu pada hasil penelitian yang sudah dilakukan oleh peneliti. Rumusan masalah penelitian terkait dengan apa saja aspek-aspek yang bertransformasi dari teks sejarah pertempuran Kotabaru ke dalam teks Beksan Bedhaya Ngadilaga Kotabaru telah terjawab pada bagian pembahasan penelitian berikut dengan prosesnya. Dalam hal ini penata tari W. Ragamulya telah berhasil mewujudkan adanya unsur teks sejarah pertempuran 7 Oktober 1945 di Kotabaru ke dalam teks Beksan Bedhaya Ngadilaga Kotabaru.

Transformasi merupakan suatu proses mengalih rupakan suatu hal ke hal yang lain dan tidak meninggalkan apa yang menjadi hipogramnya. Transformasi mengakibatkan suatu perubahan wujud yang berbeda dengan wujud aslinya. Meskipun terjadi perubahan, namun tidak sepenuhnya berubah sehingga masih bisa diidentifikasi unsur-unsur pokok yang menjadi bahan yang ditransformasikan. Alih rupa dari unsur-unsur teks sejarah pertempuran Kotabaru ke dalam Beksan Bedhaya Ngadilaga Kotabaru telah dianalisis peneliti dengan menggunakan analogi dari teori interteks beberapa tokoh sastra. Teori interteks tersebut juga digunakan dalam penelitian model transformasi unsur pewayangan oleh Burhan dan dengan mengacu pada cara kerja yang dilakukan oleh Burhan maka peneliti dapat melakukan kerja analisis pada penelitian ini.

Teori interteks telah membuktikan adanya teks yang tidak dapat berdiri sendiri dan masih berkaitan dengan teks lain yang turut membingkainya. Begitu pula yang terjadi pada teks Beksan Bedhaya Ngadilaga Kotabaru yang tidak dapat berdiri sendiri karena pada dasarnya kemunculan bedhaya ini karena adanya teks-teks lain yang terkait, yakni sejarah pertempuran Kotabaru dan teks bedhaya-bedhaya yang sudah ada sebelumnya di Keraton Yogyakarta.

Unsur-unsur intrinsik dalam karya sastra digunakan dalam penelitian ini untuk membantu dalam pengidentifikasian teks sejarah dan teks bedhaya. Teks akan dibaca berdasarkan data yang diperoleh dan dengan menganalisnya maka akan dihasilkan beberapa unsur yang bertransformasi, yang pada akhirnya menghasilkan sebuah jawaban penelitian.

Beksan Bedhaya Ngadilaga Kotabaru merupakan wujud dari transformasi teks sejarah pertempuran Kotabaru, diperkuat dengan adanya unsur-unsur intrinsik yang ditransformasikan yakni pada:

1. Unsur masalah pokok dan tema yang bertransformasi pada keseluruhan bentuk penyajian Beksan Bedhaya Ngadilaga Kotabaru, yang dituangkan melalui kandha, Bawa Sekar Ageng Madukusuma Pelog Barang, dan Gendhing Ngadilaga.

2. Unsur setting/latar yang bertransformasi pada penamaan Bedhaya Ngadilaga Kotabaru, penamaan Gendhing Kotabaru, kandha, lirik Gendhing Ngadilaga bagian pangkat ndhawah, dan lirik Gendhing Sidamukti.

3. Unsur alur yang bertransformasi pada liriklirik dalam gendhing yang disesuaikan dengan pola gerak dan pola rakit sesuai dengan elemen-elemen identifikasi alur.

4. Unsur penokohan yang bertransformasi pada peran penari Beksan Bedhaya Ngadilaga Kotabaru, terutama peran Endhel Pajeg dan Batak dengan pola lantai (rakit) dan pola gerak.

5. Unsur nilai-nilai yang bertransformasi pada keseluruhan bentuk penyajian Beksan Bedhaya Ngadilaga Kotabaru yakni perpaduan dari pola gerak, pola lantai, pola iringan, dan properti yang digunakan penari yang membangun suatu suasana dengan penggambaran sikap patriotisme dan nasionalisme dalam usaha bela negara. 
Fenomena yang ditemukan dari penelitian ini adalah adanya transformasi yang bersifat meneruskan/melanjutkan dan ada pula transformasi yang bersifat mematahkan dari hipogramnya. Secara tekstual dalam tataran permukaannya (surface structure), bentuk penyajian Beksan Bedhaya Ngadilaga Kotabaru sudah bisa disebut sebagai tari bedhaya, namun apabila ditinjau lebih dalam lagi yakni pada tataran deep structurenya, Beksan Bedhaya Ngadilaga Kotabaru belum bisa disebut sebagai bedhaya yang selalu mengindahkan konsekuensi kaidah bedhaya khususnya dari peranan Endhel Pajeg dan Batak dalam segi pengemasan bentuk penyajiannya.

\section{DAFTAR PUSTAKA:}

Ahimsa-Putra, Heddy Shri. 2001. Strukturalisme Levi-Strauss Mitos Dan Karya Satra. Yogyakarta: Galang Press.

Hadi, Y. Sumandiyo. 2012. Koreografi Bentuk-Teknik-Isi. Yogyakarta: Cipta Media.

Tim penyusun kamus Pusat Pembinaan dan Pengembangan Bahasa. 1995. "Kamus Besar Bahasa Indonesia". Jakarta: Perum Balai Pustaka, p. 1.070.

Sumaryono, 2003. Restorasi Seni Tari \& Transformasi Budaya. Yogyakarta: eLKAPHI (Lembaga Kajian Pendidikan dan Humaniora Indonesia).

Nurgiyantoro, Burhan. 1998. Transformasi QUnsur Pewayangan dalam Fiksi Indonesia. Yogyakarta: Gadjah Mada University Press.

Rudyansjah, Tony. 2009. Kekuasaan, Sejarah, \& Tindakan: Sebuah kajian tentang lanskap budaya. Jakarta: Rajawali Pers.

\section{DAFTAR NARASUMBER:}

Bagus S., 52 tahun, sebagai anak dari mantan tentara yang dahulu ikut dalam pertempuran Kotabaru.

W. Ragamulya, 40 tahun, sebagai penata iringan tari sekaligus penata Beksan Bedhaya Ngadilaga Kotabaru. 
SUSI SETYANINGSIH (Transformasi Teks Sejarah Pertempuran Kotabaru ke dalam Teks Beksan Bedhaya Ngadilaga Kotabaru)
JOGED

ISSN: $1858-3989$ 